\title{
Effect of Landscape Mulches on Desert Landscape Microclimates
}

\author{
Catherine K. Singer and Chris A. Martin
}

\begin{abstract}
Effects of three landscape mulches: 1) composted ponderosa pine residue; 2) uncomposted shredded landscape tree trimmings; and 3) screened decomposing granite, were compared over the course of 2 years (2004 to 2005) for their ability to modify air and soil landscape microclimates in Phoenix, Arizona, U.S. Temperatures at the surface of the two organic mulches were generally higher during the day and lower at night than at the surface of either decomposing granite or soil without a mulch cover. During nighttime hours, decomposing granite mulch or soil without a mulch cover emitted more long wave radiation than the two organic mulches. Conductive heat transfer through the organic mulches was generally lower than through decomposing granite. Daytime temperatures of soil at 5 and $30 \mathrm{~cm}$ (2 and 12 in) depths were generally lower beneath the two organic mulches than under decomposing granite mulch or soil without any landscape mulch cover. Soil covered with organic mulch evaporated less water than soil without mulch. Under desert conditions, the two organic mulches were more effective at moderating heat gain and water loss from soil than decomposing granite mulch because of an increased resistance to heat transfer and evaporation.

Key Words. Soil heat flux; soil water evaporation; temperature.
\end{abstract}

Organic and inorganic surface mulches have been shown to moderate temperatures within the root zone of landscape trees and shrubs (Brady and Weil 2002). In a temperate climate, Iles and Dosmann (1999) showed that soil temperatures $10 \mathrm{~cm}$ (4 in) below organic mulches were approximately $2.5^{\circ} \mathrm{C}\left(4.5^{\circ} \mathrm{F}\right)$ lower than in soil under inorganic mineral mulches. Mulches can also alter radiant heat transfer and modify landscape surface energy balances (van Donk and Tollner 2001). In a semiarid climate, Montague et al. (2000) reported that soil heat fluxes beneath a pine bark mulch were as much as $70 \mathrm{~W} / \mathrm{m}^{2}$ lower than under turfgrass. Montague and Kjelgren (2004) later reported that daytime long wave radiation fluxes in the air above pine bark mulch were greater than those above several inorganic mulches or turfgrass.

Landscape water conservation is an important consideration affecting mulch use in the southwestern United States (Martin 2001) and landscape mulches can lower soil evaporation rates (Ashworth and Harrison 1983; Litzow and Pellett 1983; Kraus 1998; Pickering et al. 1998; Li 2003). Rock and stone fragment mulches were shown to reduce cumulative evaporative soil water loss by as much as $10 \mathrm{~mm}$ (0.4 in) after 7 days (van Wesemael et al. 1996). Gravel-sand mulches were shown to reduce cumulative soil water loss by approximately $10 \mathrm{~mm}(0.4 \mathrm{in})$ after 14 days (Li 2003). Montague et al. (2007) found that applications of organic mulch and irrigations at 50\% reference evapotranspiration produced plants with acceptable landscape aesthetics.

In major southwest United States desert cities such as Phoenix, the prevalent landscape mulches are crushed stone and pumice, pebbles, and decomposing granite, and use of organic materials as landscape mulch is uncommon. In contrast, the southwest landscape industry generates copious amounts of yard waste such as tree trimmings that are usually disposed of in public landfills. In addition, selective harvest of ponderosa pine trees in the forests of Arizona and New Mexico in compliance with the U.S. government's Healthy Forests Initiative (U.S. Gov- ernment 2002) has created a regional surplus of composted pine mulch. Research comparing effects of organic and inorganic mulches on landscape surface energy balances, soil temperatures, and soil water evaporation rates in the normally hot, arid portions of the southwest is lacking.

Rapid growth of cities in the United States desert southwest has increased emphasis on sustainable landscape practices, including use of alternative landscape mulch sources. Landscape sustainability can be defined in terms of best management practices, enhanced environmental quality, and conservation of natural resources. The purpose of this research was to compare effects of two sources of recycled tree residues and decomposing granite on their ability to modify air and soil desert landscape microclimates.

\section{MATERIALS AND METHODS}

Three research experiments were conducted during 2004 and 2005 at sites within the Phoenix metropolitan region to compare effects of two organic and one inorganic mulch types on desert landscape microclimates. The city of Phoenix, Arizona, is situated at the northeast edge of the Sonoran Desert at an average elevation of $305 \mathrm{~m}(1,006.5 \mathrm{ft})$ above sea level. The climate of Phoenix is characterized by intense solar radiation, aridity, and extreme heat from May through September. Phoenix has an annual average rainfall and potential evapotranspiration of $180 \mathrm{~mm}$ (7.2 in) and 2,280 mm (91.2 in), respectively. The average summer temperature is $31^{\circ} \mathrm{C}\left(88^{\circ} \mathrm{F}\right)$, but daily summer maxima often exceed $43^{\circ} \mathrm{C}\left(110^{\circ} \mathrm{F}\right)$. Winters are mild and have an average temperature of $11^{\circ} \mathrm{C}\left(52^{\circ} \mathrm{F}\right)$. In Phoenix, the summer of 2004 was slightly climatologically warmer than 2005 (Arizona Meteorological Network 2007)

The two organic mulches were ponderosa pine residue (PPR) and landscape tree trimmings (LTT). The PPR mulch was sourced from ponderosa pine (Pinus ponderosa) logging operations on the mountainous Mogollon Rim plateau of north central 
Arizona and composted by Southwest Forest Products, Phoenix, Arizona (www.southwestforestproducts.com). The LTT mulch consisted of fresh landscape tree trimmings generated by DLC Resources Inc., Phoenix, Arizona (www.dlcresources.com) from normal management of residential common areas in the Phoenix metropolitan area and was a bulk mix of shredded branch trimmings from mostly tree species of acacia (Acacia), eucalyptus (Eucalyptus), oak (Quercus), and elm (Ulmus). These two organic mulches were compared with decomposing granite and soil without a mulch cover (control). The decomposing granite (DG) mulch was a screened $0.9 \mathrm{~cm}$ (0.36 in) minus Red Mountain Coral crushed granite rock quarried locally from the Salt River drainage in Mesa, Arizona. Table 1 shows some physical characteristics of the three mulch types.

\section{Experiment 1}

From April 2004 until October 2005, an experiment was conducted to determine effects of three landscape surface mulches on soil temperatures and radiant flux properties at an open sky, field research site in Phoenix, Arizona. Soil at the research site was a Rillito series gravelly loam (taxonomic class $=$ coarse loam, mixed, superactive, hyperthermic Typic Haplocalcid, bulk density $\left.=1.57 \mathrm{~g} / \mathrm{cm}^{3}\left[9.2 \mathrm{oz} / \mathrm{in}^{3}\right]\right)$ with a $0 \%$ to $1 \%$ slope. Cumulative rainfall and potential evapotranspiration near the research site from April 2004 to October 2005 were $499 \mathrm{~mm}$ (19.96 in) and 3,371 mm (134.84 in), respectively (Arizona Meteorological Network 2007).

In April 2004, $149 \mathrm{~m} \times 9 \mathrm{~m}(29.7 \mathrm{ft} \times 29.7 \mathrm{ft})$ nearly contiguous plots were established at the research site by removing all surface debris from each plot area. A completely randomized unbalanced experimental design was used to assign mulch treatments to each plot. The three landscape surface mulches, LTT, PPR, or DG, were applied to $12(n=4)$ of the plots at a minimum depth of $5 \mathrm{~cm}$ (2 in), the minimum depth for landscape mulches stipulated by The Arizona Department of Transportation Landscape and Irrigation Specifications, Section 430.4. The remaining two landscape plots did not receive surface mulch (bare soil control, $n=2$ ). Surrounding each of the 14 plots was a $2.5 \mathrm{~m}(8.25 \mathrm{ft})$ wide strip of nonvegetative soil without mulch. The thickness of the landscape mulch layer within each plot was recorded at the beginning and end of the experiment by making 12 measurements of mulch depth per plot in three north to south transect gradients.

Daily patterns of total irradiance $\left(\mathrm{W} / \mathrm{m}^{2}\right)$, net all wavelength radiation $\left(\mathrm{W} / \mathrm{m}^{2}\right)$, mulch and soil surface temperatures were recorded over the course of 2 weeks during spring, summer, and fall of 2004 and 2005 under clear sky conditions. Total irradiance was recorded with a LI-200S pyranometer (Li-Cor Biosciences, Lincoln, NE) horizontally leveled on the top of the mulch surface at the center of each mulch plot. Net all wavelength radiation was recorded with a Q7_1-L REBS net radiometer (Campbell Scientific, Logan, UT) horizontally positioned at the center of each plot at a height of $1 \mathrm{~m}(3.3 \mathrm{ft})$ above the mulch treatment plot surface. Using a 21X micrologger (Campbell Scientific, Logan, UT), total irradiance and net radiation data were recorded every $300 \mathrm{sec}$, averaged for each $15 \mathrm{~min}$ interval, and integrated for each $6 \mathrm{hr}$ interval. Long wave radiation was calculated as the numeric difference between total irradiance and net radiation. Surface temperatures of mulch and bare soil without mulch (control) were recorded every $4 \mathrm{hr}$ with a handheld Oakton InfraPro Infrared Thermometer (emissivity $=0.94$, $7^{\circ}$ field of view; Oakton Instruments, Vernon Hills, IL) at approximately $30 \mathrm{~cm}$ (12 in) above the mulch surface.

Soil temperatures were recorded every 2 hrs from January 2004 (3 months before mulch treatment installation) until November 2005 using Watch Dog model 100 data loggers (Spectrum Technologies, Plainfield, IL). The Watch Dog data loggers were positioned 5 and $30 \mathrm{~cm}$ ( 2 and 12 in) beneath the soil surface at the center of each mulch treatment plot. Monthly records of soil moisture content were made within each plot with a portable Field Scout TDR 100 Soil Moisture probe (Spectrum Technologies) inserted into the soil to a depth of $5 \mathrm{~cm}$ (2 in).

\section{Experiment 2}

Another experiment was conducted to determine dry bulk density, thermal conductivity, and surface albedo of the PPR, LTT, and DG mulches. Mulch dry bulk densities were calculated as the weight of five oven-dried mulch $\left(72 \mathrm{hrs}\right.$ at $\left.105^{\circ} \mathrm{C}\left[221^{\circ} \mathrm{F}\right]\right)$ samples divided by the volume occupied by each mulch sample. Thermal conductivity $\left(\mathrm{W} / \mathrm{m}^{\circ} \mathrm{C}\right)$ values of each mulch type were calculated using a modified protocol of Montague and Kjelgren (2004). Surface albedo of the PPR, LTT, and DG mulches were determined at the research site described previously in Experiment 1.

For thermal conductivity, three $45 \mathrm{~cm} \times 60 \mathrm{~cm}(18$ in $\times 24$ in) Styrofoam box containers per mulch type were filled with a $5 \mathrm{~cm}$ ( 2 in) layer of air-dried, screened soil from the research site described in Experiment 1. On top of the layer of soil was placed a $5 \mathrm{~cm}$ (2 in) layer of air-dried mulch. A soil heat flux plate (HFT3 Soil Heat Flux Plate; Campbell Scientific) and copperconstantan thermocouple was placed on the soil surface beneath the mulch at the center of each Styrofoam box. The Styrofoam box containers were then placed in a polycarbonate-covered greenhouse (30\% light exclusion) maintained at $38^{\circ} \mathrm{C}\left(100^{\circ} \mathrm{F}\right) /$ $24^{\circ} \mathrm{C}\left(75^{\circ} \mathrm{F}\right)$ ambient daytime/nighttime temperatures and allowed to acclimate for $72 \mathrm{hrs}$. Once acclimated, diurnal records of heat flux and temperature were made every $10 \mathrm{sec}$ by a micrologger (Model 23X micrologger; Campbell Scientific) and averaged for $30 \mathrm{~min}$ intervals. Midday (1400 HR) mulch surface temperatures in each box were recorded with a handheld Oakton InfraPro Infrared Thermometer positioned approximately $2.5 \mathrm{~cm}$ ( 1 in) above the measurement surface. Midday total irradiance at the mulch surface was $814 \mathrm{~W} / \mathrm{m}^{2}$ (LI-200S pyranometer; Li-Cor

Table 1. Landscape surface mulch physical characteristics ( \pm SE): particle size, bulk density, thermal conductivity, and albedo of landscape tree trimmings (LTT), ponderosa pine residue (PPR), and decomposing granite (DG).

\begin{tabular}{|c|c|c|c|c|}
\hline $\begin{array}{l}\text { Landscape } \\
\text { mulch }\end{array}$ & Mulch particle size grade & $\begin{array}{l}\text { Bulk } \\
\text { density }\left(\mathrm{g} / \mathrm{cm}^{3}\right)\end{array}$ & $\begin{array}{l}\text { Thermal conductivity at } \\
38^{\circ} \mathrm{C}\left(100^{\circ} \mathrm{F}\right)\left(\mathrm{W} / \mathrm{m}^{\circ} \mathrm{C}\right)\end{array}$ & Albedo \\
\hline LTT & Approx. $1.9 \mathrm{~cm}(0.76 \mathrm{in})$ minus unscreened & $0.24 \pm 0.08$ & $0.05 \pm 0.002$ & $0.16 \pm 0.003$ \\
\hline PPR & $1.9 \mathrm{~cm}(0.76 \mathrm{in})$ minus screened & $0.25 \pm 0.08$ & $0.05 \pm 0.002$ & $0.16 \pm 0.003$ \\
\hline DG & $0.9 \mathrm{~cm}(0.36 \mathrm{in})$ minus screened & $1.69 \pm 0.07$ & $0.18 \pm 0.007$ & $0.20 \pm 0.003$ \\
\hline
\end{tabular}


Biosciences). Mulch thermal conductivity $\left(\mathrm{k}_{\mathrm{m}}\right)$ was calculated according to

$$
\mathrm{km}=\mathrm{Gm} *\left(\mathrm{~d} /\left[\mathrm{T}_{\text {soil }}-\mathrm{T}_{\text {surface }}\right]\right)
$$

where $G_{m}$ was the measured heat flux through the mulch $\left(\mathrm{W} / \mathrm{m}^{2}\right), \mathrm{T}_{\text {soil }}$ was the temperature of the soil surface below the mulch, $\mathrm{T}_{\text {surface }}$ was the mulch surface temperature, and $\mathrm{d}$ was mulch layer thickness (m). Conductive heat transfer (C) through each mulch type was then calculated according to Fourier's law of conductive heat transfer using temperature data recorded in Experiment 1 during August 2004 and July 2005 according to

$$
\mathrm{C}=-\mathrm{km} *\left(\left[\mathrm{~T}_{\text {soil }}-\mathrm{T}_{\text {surface }}\right] / \mathrm{d}\right)
$$

where $\mathrm{k}_{\mathrm{m}}$ was the thermal conductivity of the mulch $\left(\mathrm{W} / \mathrm{m}^{\circ} \mathrm{C}\right)$, $\mathrm{T}_{\text {soil }}$ was the temperature of the soil surface below the mulch, $\mathrm{T}_{\text {surface }}$ was the mulch surface temperature, and $\mathrm{d}$ was mulch layer thickness $(\mathrm{m})$.

For surface albedo, total irradiance and reflected all wavelength radiation ( $\mathrm{mV}$ DC) were recorded in the summers of 2004 and 2005 with a LI-200S pyranometer (Li-Cor Biosciences) attached to a stick (approximately $1 \mathrm{~m}[3.3 \mathrm{ft}]$ length) at midday (approximately $1400 \mathrm{HR}$ ) at the center of each of the landscape plots described previously in Experiment 1. Below the pyranometer, a toothpick attached to the stick was used to determine the incident sun angle. Mulch surface albedo was calculated as the ratio of incoming all-wave radiation to reflected all-wave radiation.

\section{Experiment 3}

A third experiment was conducted for 22 days (31 May to 21 June 2005) at an open sky, graded field site on the Polytechnic campus of Arizona State University (Mesa, AZ) to determine temporal patterns of evaporative water loss and moisture content of soil covered by the PPR, LTT, or DG mulches previously described. Bare soil without a mulch cover was used as a fourth control treatment. During the 22-day experiment, ambient air temperatures ranged from a minimum of $19^{\circ} \mathrm{C}\left(66^{\circ} \mathrm{F}\right)$ to a maximum of $45^{\circ} \mathrm{C}\left(113^{\circ} \mathrm{F}\right)$ with a mean of $31^{\circ} \mathrm{C}\left(88^{\circ} \mathrm{F}\right)$; mean maximum daytime irradiance was $1,203 \mathrm{~W} / \mathrm{m}^{2}$ and there was no rainfall (local weather data courtesy of the Arizona State University Polytechnic Photovoltaic Testing Laboratory, Mesa, AZ). Total potential evapotranspiration was $167 \mathrm{~mm}$ (6.68 in) (http:// ag.arizona.edu/azmet).

Sixteen containers were constructed out of $30 \mathrm{~cm}$ (12 in) sections of $15 \mathrm{~cm}$ (6 in) diameter polyvinyl chloride (PVC) pipe with solid PVC bottoms. These 5.3 L (1.38 gal) PVC containers were constructed to determine temporal patterns of evaporative water loss and moisture content of mulch-covered soil. At the bottom of each container, nine, $5 \mathrm{~mm}$ ( $0.2 \mathrm{in})$ holes were drilled in a uniform pattern to allow for gravitational water loss and plastic mesh screens were inserted at the bottom of each container to prevent loss of soil. Each container was filled with either $7.5 \mathrm{~kg}(16.5 \mathrm{lb})$ (containers with mulch) or $9 \mathrm{~kg}(19.8 \mathrm{lb})$ (containers without mulch) of air-dried, sieved (5 mm [0.2 in] screen) and uniformly mixed soil (dry bulk density $=1.57$ $\left.\mathrm{g} / \mathrm{cm}^{3}\left[9.2 \mathrm{oz} / \mathrm{in}^{3}\right]\right)$ from the research site described previously in Experiment 1. On top of the column of soil in each of the PVC containers was later placed a $5 \mathrm{~cm}$ (2 in) layer of each mulch type as described subsequently except for the bare soil control containers.
Sixteen square plots $\left(0.58 \mathrm{~m}^{2}\left[6.24 \mathrm{ft}^{2}\right] / \mathrm{plot}\right)$ at an open field site that was graded and leveled were established in a four by four grid within a $100 \mathrm{~m}^{2}\left(1076 \mathrm{ft}^{2}\right)$ area in a randomized complete block design arrangement with four blocked replications. The 16 plots were equidistant from each other and separated by a $1 \mathrm{~m}(3.3 \mathrm{ft})$ buffer of bare soil. Around the perimeter of each plot was a wood border embedded in the soil such that $5 \mathrm{~cm}$ ( 2 in) of the wood border was above the plot surface grade. On 31 May 2005, the soil-filled PVC containers were placed vertically into the soil at the center of each plot so that the surface grade within each PVC container and surrounding plot was the same. Next, a $5 \mathrm{~cm}$ ( 2 in) layer of one of the three surface mulch treatments was placed on the surface of each plot, including the surface of each PVC cylinder, except the bare soil control cylinders. The soil-filled PVC containers with or without surface mulch covers $(n=4)$ remained in place for 5 days to acclimatize to field conditions.

After 5 days, the PVC containers were removed from the plots and transported to a nearby laboratory where $1.7 \mathrm{~L}(0.44 \mathrm{gal})$ (except $1.8 \mathrm{~L}$ [0.47 gal] in bare soil containers) of distilled water $\left(25^{\circ} \mathrm{C}\left[70^{\circ} \mathrm{F}\right]\right)$ was added in small increments to each container. A preliminary experiment was conducted to determine the amount of distilled water needed to bring the air-dried soil in each container to field capacity with minimal gravitational water loss from the bottom of each container. The weight of each of the containers at field capacity was recorded after all water had stopped draining from the container bottom. The PVC containers were then repositioned into their respective field plot locations.

At $48 \mathrm{hr}$ intervals (0600 HR for 22 days), the PVC containers were removed from their plot locations and weighed. The change in container weight was assumed to be the result of soil evaporative water loss. After the measurements, the PVC containers were immediately repositioned into their respective field plot locations.

\section{Data Analysis}

An analysis of variance was calculated for each data set using a general linear model (JMP 5.0.1; SAS Institute Inc., Cary, NC). For Experiment 1, Type IV sums of squares was used because of unequal plot replication and means and standard errors of the mean were calculated for soil temperatures at 5 and $30 \mathrm{~cm}$ ( 2 and 12 in) depths, soil surface temperatures, and mulch surface temperatures, and integrated net radiation values by mulch treatment. If significant differences were found, treatment means were separated by Tukey's multiple comparisons test at the level $P \leq 0.05$. Simple Pearson's correlations of summer net radiation and pyranometer measurements were calculated. For Experiment 3, a one-way univariate model with surface mulch type as the independent variable with Type III sums of squares was used for statistical comparisons of evaporative soil water loss.

\section{RESULTS}

\section{Experiment 1}

Soil moisture content within each of the 14 mulch plots ranged from an average of $20 \%$ volumetric water content in March 2005 after an El Nino-enhanced 2004 to 2005 winter rainy season to an average of $6 \%$ volumetric water content during the hot, dry summer months and was not significantly affected by mulch cover type (data not shown). Over the course of two growing seasons, LTT, PPR, and DG mulches decreased in depth by $48 \%$, $27 \%$, and $19 \%$, respectively. 


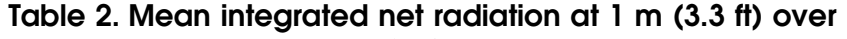
landscape tree trimmings (LTT), ponderosa pine residue (PPR), decomposing granite (DG), or bare soil without a mulch cover (control) by day (0600 to $1900 \mathrm{HR}$ ) and night (1900 to 0600 HR) during August 2004 and July 2005.

\begin{tabular}{llllll}
\hline & \multicolumn{4}{c}{ Net radiation $\left(\mathrm{MJ} / \mathrm{m}^{2}\right)$} \\
\cline { 2 - 3 } \cline { 5 - 6 } Treatment & Day & Night & & Day & Night \\
\cline { 2 - 5 } \cline { 5 - 7 } & $10.77^{\mathrm{z}} \mathrm{a}^{\mathrm{y}}$ & $-1.61 \mathrm{a}$ & & $12.97 \mathrm{a}$ & $-1.59 \mathrm{a}$ \\
LTT & $9.35 \mathrm{a}$ & $-1.60 \mathrm{a}$ & & $12.78 \mathrm{a}$ & $-1.66 \mathrm{a}$ \\
PPR & $10.43 \mathrm{a}$ & $-2.57 \mathrm{~b}$ & & $11.23 \mathrm{a}$ & $-2.73 \mathrm{~b}$ \\
DG & $10.35 \mathrm{a}$ & $-2.75 \mathrm{~b}$ & & $12.97 \mathrm{a}$ & $-2.67 \mathrm{~b}$ \\
Control & & & & &
\end{tabular}

${ }^{\mathrm{z}}$ Values are treatment means, $n=4$.

${ }^{y}$ Mean values within the same column followed by the same letter were not significantly different using Tukey's honestly significant difference test $(\alpha=0.05)$.

Although radiation and mulch surface temperature data were collected seasonally or continuously for 2 years, we have chosen to present only the daily mean patterns for the summer months of August 2004 and July 2005 because they best demonstrate the ability of different surface mulch treatments to buffer soil from intense radiation energy typical in a hot desert climate. Generally, integrated mean values of net radiation over the surface mulch treatments were positive during the day and negative during the night (Table 2). During both August 2004 and July 2005, daytime net radiation values over all mulch treatments were similar, and positive daytime values were positively correlated with mean insolation $(\mathrm{r}=0.9188)$. During both August 2004 and July 2005, nighttime (1900 HR to 0600 HR, no direct insolation) net radiation values over LTT and PPR mulches were less negative than over DG mulch of soil without mulch. Concomitantly, nighttime long wave radiation values emitted by the LLT and PPR mulches were significantly less than over DG mulch of soil without mulch (Table 3).

Patterns of mulch surface temperatures for both August 2004 and July 2005 were similar (Figure 1A-B). The LTT and PPR mulches had the highest surface temperatures at $1000 \mathrm{HR}$ and $1400 \mathrm{HR}$ and the lowest surface temperatures at $2200 \mathrm{HR}$. At $1400 \mathrm{HR}$, the mean surface temperatures of the two organic mulches were approximately $62^{\circ} \mathrm{C}\left(143^{\circ} \mathrm{F}\right)$ and $68^{\circ} \mathrm{C}\left(154^{\circ} \mathrm{F}\right)$ during August 2004 and July 2005, respectively. By $2200 \mathrm{HR}$, mean surface temperatures of the two

Table 3. Mean nighttime (1900 to $0600 \mathrm{HR}$ ) long wave radiation over landscape tree trimmings (LTT), ponderosa pine residue (PPR), decomposing granite (DG), or bare soil without a mulch cover (control) during August 2004 and July 2005.

\begin{tabular}{llc}
\hline & \multicolumn{2}{c}{ Long wave radiation $\left(\mathrm{W} / \mathrm{m}^{2}\right)$} \\
\cline { 2 - 3 } Treatment & 2004 & 2005 \\
\hline LTT & $38.8^{\mathrm{z}} \mathrm{b}^{\mathrm{y}}$ & $49.2 \mathrm{~b}$ \\
PPR & $37.9 \mathrm{~b}$ & $45.5 \mathrm{~b}$ \\
DG & $61.6 \mathrm{a}$ & $83.0 \mathrm{a}$ \\
Control & $61.2 \mathrm{a}$ & $70.6 \mathrm{a}$ \\
\hline
\end{tabular}

${ }^{\mathrm{z}}$ Values are treatment means, $n=4$.

${ }^{\mathrm{y}}$ Mean values within the same column followed by the same letter were not significantly different using Tukey's honestly significant difference test $(\alpha=0.05)$. organic mulches were approximately $4^{\circ} \mathrm{C}\left(7^{\circ} \mathrm{F}\right)$ and $8^{\circ} \mathrm{C}$ $\left(14^{\circ} \mathrm{F}\right)$ cooler during August 2004 and July 2005, respectively, than the surface temperature of the DG mulch or soil without mulch.

For all treatments, soils were warmest during the seasonally hot summer months and were coolest during the winter months. Moreover, the amplitudes of the daily patterns of soil temperatures were greatest during the summer months and at the $5 \mathrm{~cm}$ depth. Mean daily temperature fluctuations tended to be lower during the spring and fall months and at the $30 \mathrm{~cm}$ depth and were lowest in soils covered by the LTT and PPR mulches. Although soil temperatures at the two depths were recorded continuously for 2 years, we present only the mean daily soil temperature data for the months of August 2004 and July 2005 because these data are sufficient to show the capacity of different surface mulch treatments to moderate the microclimate of landscape soil (Figure 2A-D).

At $5 \mathrm{~cm}$ (2 in) depth, temperatures of soil without a mulch cover exceeded $40^{\circ} \mathrm{C}\left(104^{\circ} \mathrm{F}\right)$ for approximately $12 \mathrm{hrs}$ and $9 \mathrm{hrs}$ per day during August 2004 and July 2005, respectively (Figures
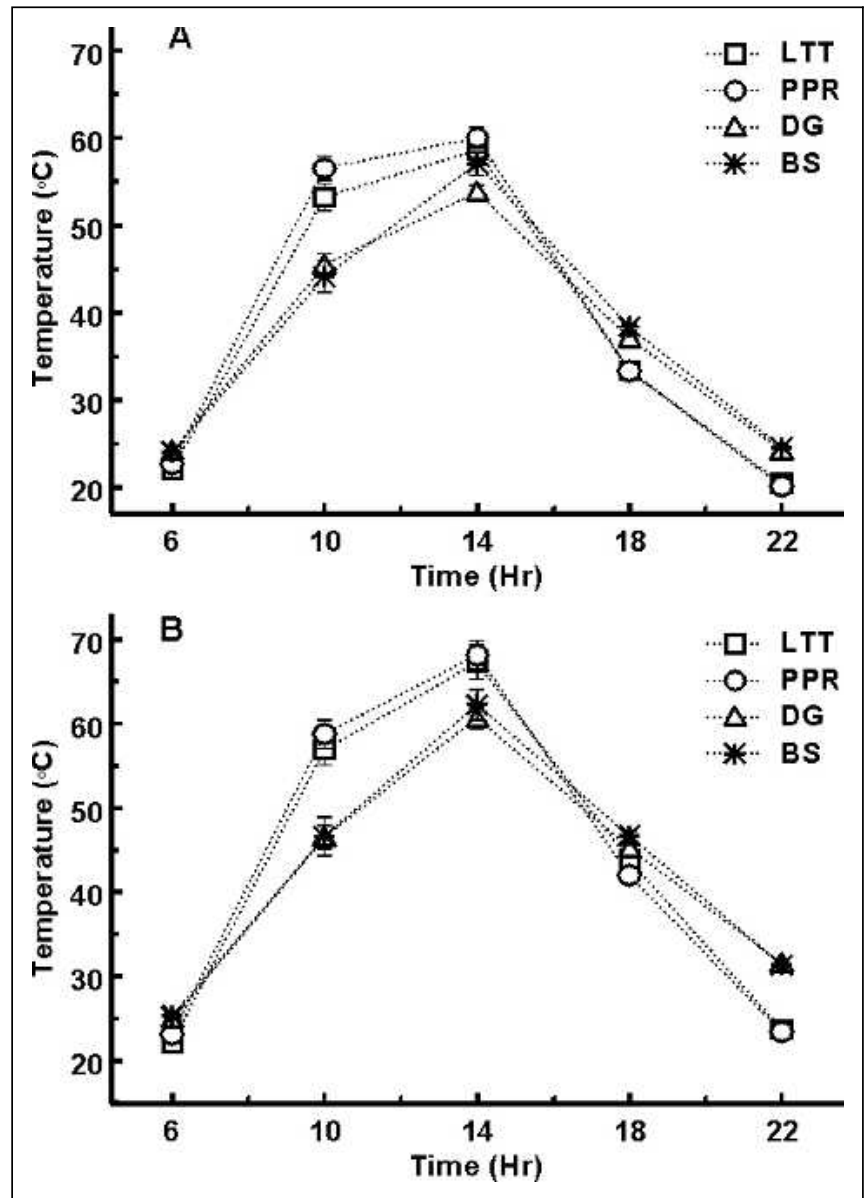

Figure 1. Effect of landscape tree trimmings (LTT), ponderosa pine residue (PPR), decomposing granite (DG), and bare soil without a mulch cover (control) on mean landscape surface temperatures (0600 to 2200 HR) during: (A) August 2004 and (B) July 2005. Values are treatment means ( $n=36$ for $L T$ and PPR mulch, $n=18$ for control soil without mulch cover). Vertical lines represent \pm SE of the means; where not visible, \pm SE is smaller than symbol size. 


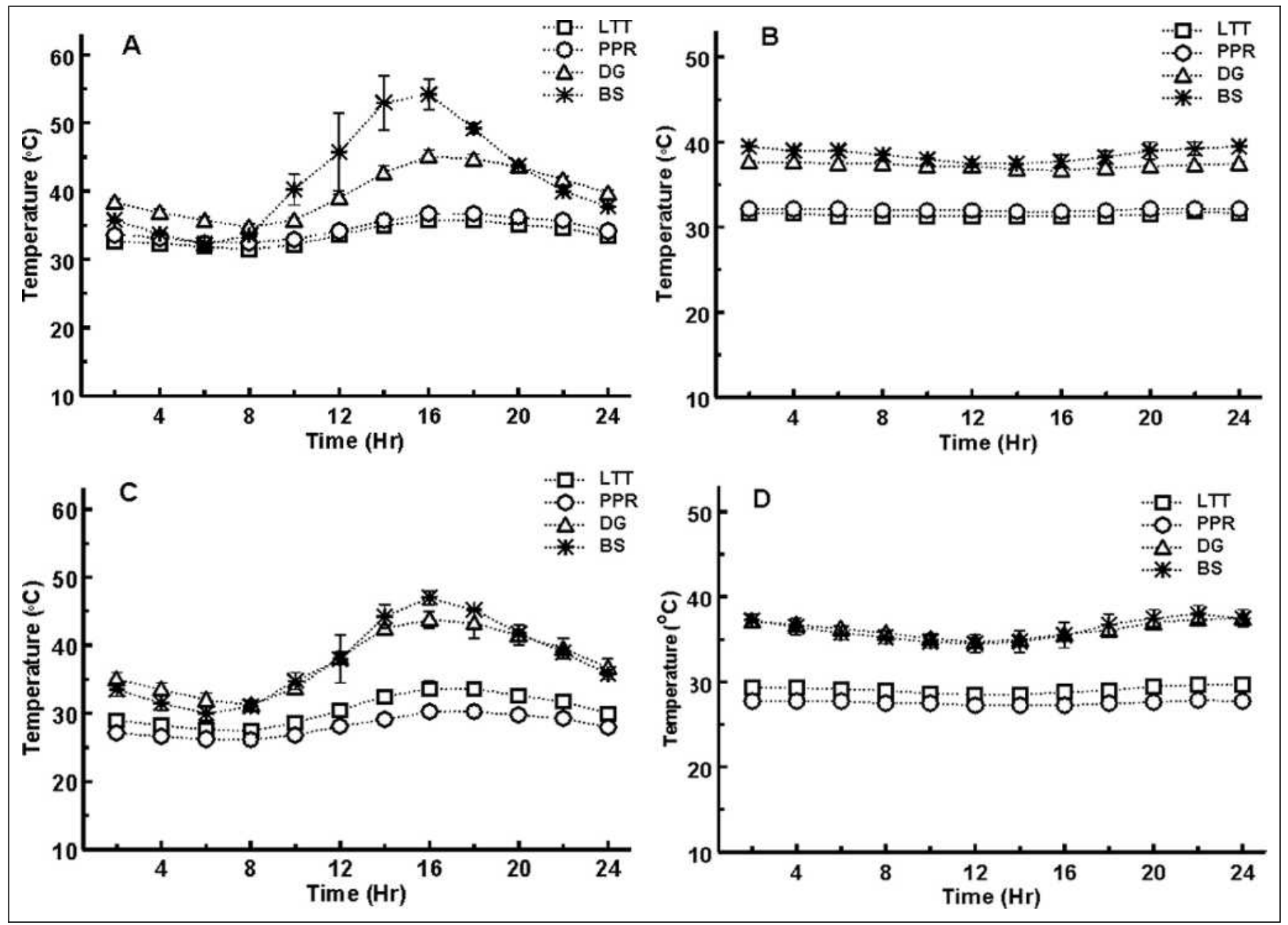

Figure 2. Effect of landscape tree trimmings (LTT), ponderosa pine residue (PPR), decomposing granite (DG), and bare soil without a mulch cover (control) on mean summer daily patterns of soil temperature at (A) $5 \mathrm{~cm}$ ( 2 in) depth, August 2004 ; (B) $5 \mathrm{~cm}$ (2 in) depth, July 2005; (C) $30 \mathrm{~cm}$ (12 in) depth, August 2004; and (D) $30 \mathrm{~cm}$ (12 in) depth, July 2005 . Values are treatment means $(n=4)$. Vertical lines represent \pm SE of the means; where not visible, \pm SE is smaller than symbol size.

2A and C). Similarly, temperatures of soil covered by DG mulch exceeded $40^{\circ} \mathrm{C}\left(104^{\circ} \mathrm{F}\right)$ for approximately $10 \mathrm{hrs}$ and $9 \mathrm{hrs}$ per day during August 2004 and July 2005, respectively. At $5 \mathrm{~cm}$ ( 2 in) depth, temperatures of soil covered by the PPR or LLT mulches did not exceed $40^{\circ} \mathrm{C}\left(104^{\circ} \mathrm{F}\right)$ at any time and averaged during the afternoon between $13^{\circ} \mathrm{C}\left(23^{\circ} \mathrm{F}\right)$ and $22^{\circ} \mathrm{C}$ $\left(40^{\circ} \mathrm{F}\right)$ lower than soils covered with $\mathrm{DG}$ mulch or without mulch. Highest mean temperatures $\left(54^{\circ} \mathrm{C}\left[129^{\circ} \mathrm{F}\right]\right)$ were recorded during August 2004 approximately $1600 \mathrm{HR}$ in soils without mulch.

At $30 \mathrm{~cm}$ (12 in) depth, soils covered with LTT or PPR mulch lacked any daily change in temperature (Figure 2B and D). Soils covered with DG mulch or without mulch were approximately $8^{\circ} \mathrm{C}\left(14^{\circ} \mathrm{F}\right)$ to $10^{\circ} \mathrm{C}\left(18^{\circ} \mathrm{F}\right)$ warmer than LTT or PPR mulched soil and were usually warmest during the night (2000 HR to $2400 \mathrm{HR}$ ) and coolest during the day (1000 HR to $1400 \mathrm{HR}$ ). During August 2004 or July 2005, mean soil temperatures at 30 $\mathrm{cm}$ (12 in) depth did not reach $40^{\circ} \mathrm{C}\left(104^{\circ} \mathrm{F}\right)$, except for soil without mulch during August 2004 (Figure 2B). Mean temperatures of soils covered with either LTT or PPR mulch ranged from approximately $28^{\circ} \mathrm{C}\left(82^{\circ} \mathrm{F}\right)$ to $32^{\circ} \mathrm{C}\left(90^{\circ} \mathrm{F}\right)$.

\section{Experiment 2}

The DG mulch had greater bulk density, higher thermal conductivity, and higher albedo than the LTT or PPR mulches (Table 1). The measured albedo value for bare soil was 0.18. Calculated estimates of mulch conductive heat transfer (C) were highest during the day and lowest at night for the DG mulch (Figure $3 \mathrm{~A}-\mathrm{B}$ ). Estimated daily patterns of $\mathrm{C}$ were similar for the PPR and LTT mulches. The daily range of $\mathrm{C}$ for DG mulch was $84 \mathrm{~W} / \mathrm{m}^{2}$ and $82 \mathrm{~W} / \mathrm{m}^{2}$ in August 2004 and July 2005, respectively. In comparison, daily range of $\mathrm{C}$ through PPR and LTT mulches was only $39 \mathrm{~W} / \mathrm{m}^{2}$ to $44 \mathrm{~W} / \mathrm{m}^{2}$ for August 2004 and July 2005, respectively.

\section{Experiment 3}

Soil in cylinders that were not treated with surface mulch evaporated significantly more soil water than soils treated with surface mulch $(P<0.0001$; Figure 4). After 22 days, cumulative water loss from soils without a mulch cover was approximately $70 \mathrm{~mm}$ (2.8 in). In contrast, soils in cylinders covered with LTT lost only approximately $31 \mathrm{~mm}$ (1.24 in). Soil in cylinders mulched with PPR or LTT evaporated soil water at similar rates 


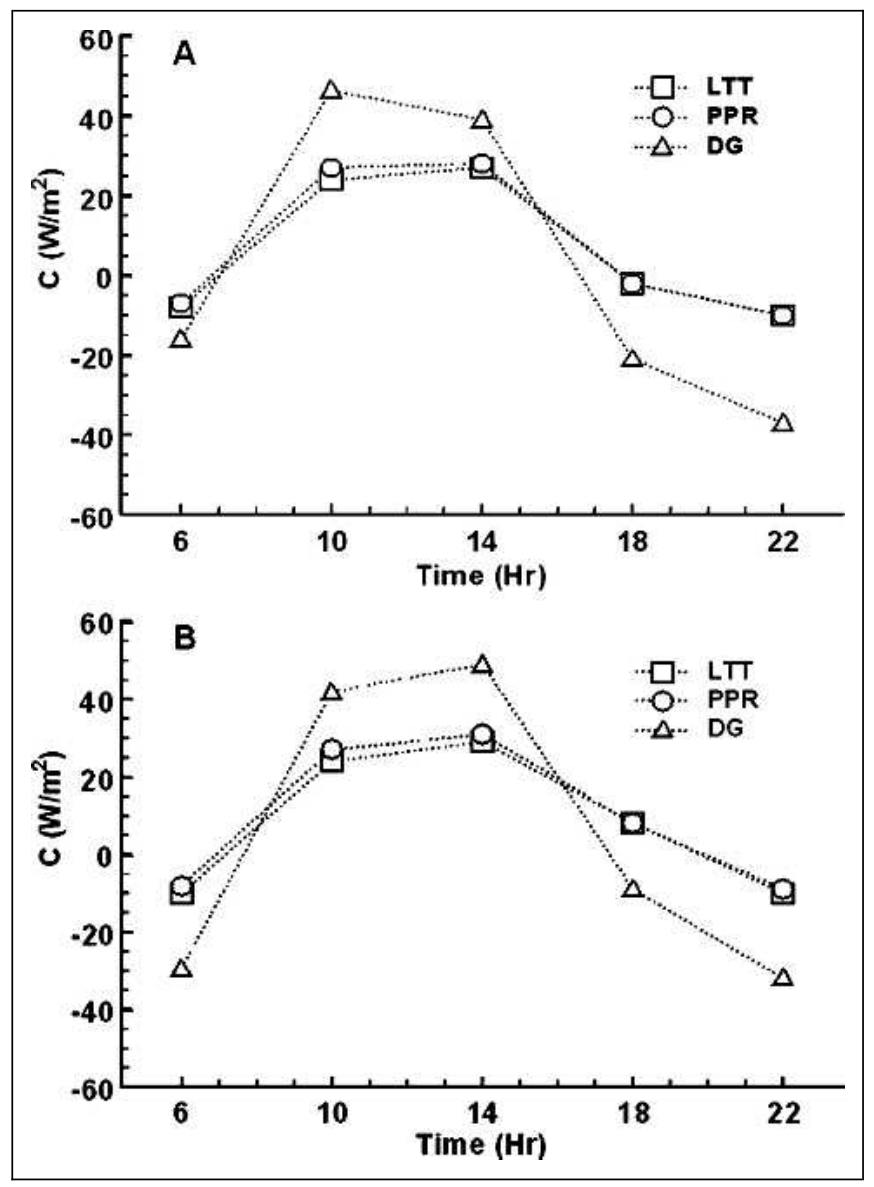

Figure 3. Calculated summer daily patterns of conductive heat transfer $(C)$ through three landscape mulches: landscape tree trimmings (LTT), ponderosa pine residue (PPR), and decomposing granite (DG) at landscape plots in Phoenix, Arizona during (A) August 2004 and (B) July 2005. Mulches depth was approximately $5 \mathrm{~cm}$ (2 in).

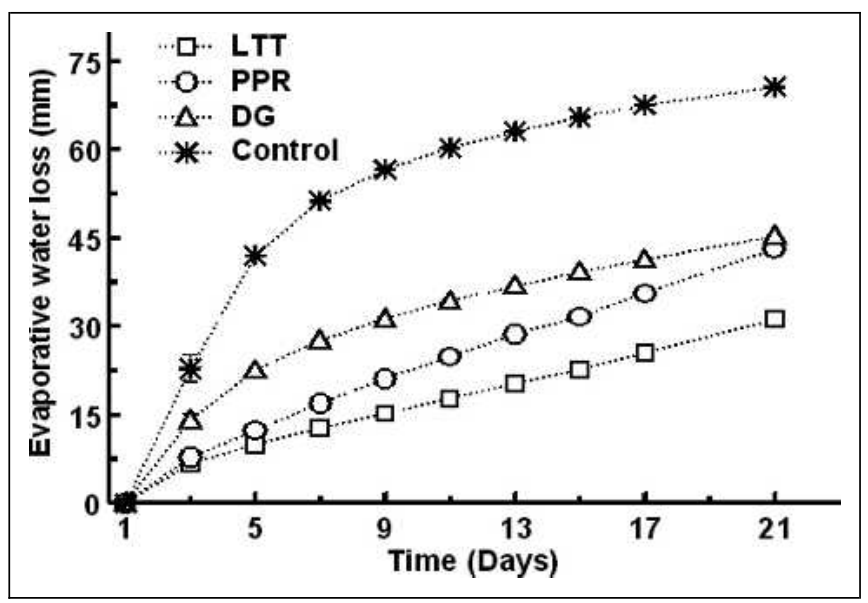

Figure 4. Cumulative evaporative water loss $(\mathrm{mm})$ during June $\mathbf{2 0 0 5}$ from soil in open field evaporation cylinders under landscape tree trimmings (LTT), ponderosa pine residue (PPR), decomposing granite (DG), or bare soil without a mulch cover (control) in Phoenix, Arizona. Values are treatment means $(n=4)$; vertical lines represent \pm SE of the means; where not visible, $\pm \mathrm{SE}$ is smaller than symbol size. at the beginning of the experiment. However, cumulative water loss under PPR was more similar to DG mulch than LTT mulch after 22 days.

\section{DISCUSSION}

Previous reports about landscape mulches (Ashworth and Harrison 1983; Iles and Montague et al. 1998, 2000; Pickering et al. 1998; Dosmann 1999) were of research conducted in regions that are more temperate and mesic than the hot desert climate of Phoenix, Arizona. The focus of this research was to determine the effectiveness of organic and inorganic mulches at altering the near surface and belowground microclimates in landscapes characterized by intense radiation and extreme aridity throughout the growing season. In general, we found that PPR and LTT mulches moderated radiant heat transfer and evaporative water loss of soil compared with DG mulch or bare soil.

The ability of surface mulches to moderate landscape soil temperatures is a function of mulch thermal properties such as albedo, thermal conductivity, bulk density, thermal conductivity, and mulch layer thickness (Holman 1986; Abu-Hamdeh and Reeder 2000). We found that LTT and PPR mulches had lower albedo than DG mulch, which implied that the two organic mulches absorbed a greater percentage of incident direct insolation. Concomitantly, we found that the LTT and PPR mulches had lower thermal conductivity than the DG mulch that resulted in a moderation of conductive heat transfer through the mulch into the soil beneath. The ramifications of these properties were that LTT and PPR mulches were warmer at the surface during times of highest incident insolation but had lower surface temperatures at night than DG mulch or soil without mulch. Although somewhat cooler at the surface during midday, the greater thermal conductivity and conductive heat transfer by the DG mulch resulted in soils temperatures at 5 and $30 \mathrm{~cm} \mathrm{(2} \mathrm{and}$ 12 in) underneath the DG mulch that were generally higher than under the LTT or PPR mulches.

These data clearly show that organic mulches can better insulate landscape soils from intense solar radiation in a hot desert climate than inorganic mulches or no mulch. In this study, soil temperatures $5 \mathrm{~cm}$ ( 2 in) below the DG mulch were $3^{\circ} \mathrm{C}$ to $9^{\circ} \mathrm{C}$ $\left(5^{\circ} \mathrm{F}\right.$ to $\left.16^{\circ} \mathrm{F}\right)$ lower than beneath bare soil controls. In contrast, $\mathrm{Li}$ (2003) from a semiarid region of China observed soil temperatures beneath a gravel-sand mulch to be between $0.5^{\circ} \mathrm{C}$ and $4.5^{\circ} \mathrm{C}\left(0.9^{\circ} \mathrm{F}\right.$ and $\left.8.1^{\circ} \mathrm{F}\right)$ higher than below soil with no mulch cover. In England, Pickering et al. (1998) observed soil surface temperatures under bark mulch and green waste compost approximately $5^{\circ} \mathrm{C}\left(9^{\circ} \mathrm{F}\right)$ lower than soil with no mulch. In North Carolina, Skroch et al. (1992) found that organic mulches reduced maximum daily temperatures at the soil surface by $2.2^{\circ} \mathrm{C}$ to $3.3^{\circ} \mathrm{C}\left(4.0^{\circ} \mathrm{F}\right.$ to $\left.5.9^{\circ} \mathrm{F}\right)$ and increased minimum daily temperatures by $1.1^{\circ} \mathrm{C}$ to $2.2^{\circ} \mathrm{C}\left(1.9^{\circ} \mathrm{F}\right.$ to $\left.4.0^{\circ} \mathrm{F}\right)$. In comparison, in a hot desert climate, mean maximum soil surface temperatures under the landscape tree trimming and ponderosa pine mulches were approximately $10^{\circ} \mathrm{C}$ to $20^{\circ} \mathrm{C}\left(18^{\circ} \mathrm{F}\right.$ to $\left.36^{\circ} \mathrm{F}\right)$ lower than bare soil. Mulch surface temperatures of pine mulch reached in excess of $60^{\circ} \mathrm{C}\left(140^{\circ} \mathrm{F}\right)$ in both this study and in the semiarid climate of Salt Lake City, Utah (Montague et al. 1998).

Our experimentally derived value for thermal conductivity of PPR and LTT mulches at $38^{\circ} \mathrm{C}\left(100^{\circ} \mathrm{F}\right)$ was determined to be $0.05 \mathrm{~W} \mathrm{~m}^{-1}{ }^{\circ} \mathrm{C}^{-1}$ in a completely dry system, whereas Montague and Kjelgren (2004) reported thermal conductivity of pine bark 
to be $0.12 \mathrm{~W} \mathrm{~m}^{-1}{ }^{\circ} \mathrm{C}^{-1}$ (at the time of greatest surface temperature) in a partially moist system in a semiarid climate. Except for landscape irrigation, moisture inputs into landscape soils in Phoenix are extremely low and soils are normally dry. Montague and Kjelgren (2004) report that their soil was generally moist at the mulch-soil interface. Because moisture content is well known to affect soil thermal conductivity, differences between these values may be attributed to differing thermal and moisture regimes in each climate.

It is generally believed that use of mulch conserves soil moisture by increasing boundary layer resistance to evaporative water loss and increasing water infiltration (Brady and Weil 2002) and many studies support this supposition about organic (Ashworth and Harrison 1983; Smith and Rakow 1992; Kraus 1998; Pickering et al. 1998; Iles and Dosmann 1999) and inorganic mulches (Smith and Rakow 1992; Kraus 1998). Li (2003) found that gravel-sand mulches reduced cumulative soil water loss by approximately $10 \mathrm{~mm}(0.4 \mathrm{in})$ after 14 days. In comparison, we found that after 22 days, PPR and LTT mulches reduced cumulative soil water loss by approximately $25 \mathrm{~mm}$ ( $1 \mathrm{in})$, whereas LTT mulch reduced water loss by approximately $40 \mathrm{~mm}$ (1.6 in).

\section{CONCLUSION}

The ability of organic mulches to modify above- and belowground landscape thermal environments has many implications and applications. We have shown that organic mulches can be used in the hot and arid climate of the desert southwest to conserve soil moisture and protect landscape plant rhizosphere from soil temperatures in excess of $40^{\circ} \mathrm{C}\left(104^{\circ} \mathrm{F}\right)$. We have shown that organic mulches lower high soil temperature extremes by resisting the influx of radiant heat energy into landscape soil. Moreover, these findings suggest that organic mulches may be used as an urban heat island management strategy, particularly in arid, desert southwest cities where urban heating is a nighttime phenomenon (Baker et al. 2002). Although organic mulches are not the normative mulch used in the desert southwest by landscape managers, our research showed that use of organic mulch in a hot desert climate can be more effective than inorganic mulches to ameliorate landscape soil thermo- and hydrodynamics. Future studies could determine how differential landscape irrigation regimes affect organic mulch thermal conductivity and how organic mulches might affect soil carbon and nitrogen chemistry and landscape plant resiliency to desert climate extremes.

Acknowledgments. We are grateful to the International Society of Arboriculture and the John Z. Duling TREE Fund for the funding to conduct this research project.

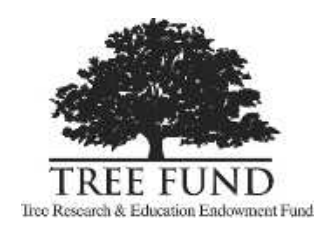

\section{LITERATURE CITED}

Abu-Hamdeh, N.H., and R.C. Reeder. 2000. Soil thermal conductivity: Effects of density, moisture, salt concentration, and organic matter. Journal American Society of Soil Science 64:1285-1290.

Arizona Meteorological Network (AZMET). Extension Biometeorology Program. College of Agriculture. University of Arizona Cooperative Extension. http://ag.arizona.edu/azmet/ (accessed 10/30/07).
Ashworth, S., and H. Harrison. 1983. Evaluation of mulches for use in the home garden. HortScience 18:180-182.

Baker, L.A., A.J. Brazel, N. Selover, C.A. Martin, N. McIntyre, F.R. Steiner, A. Nelson, and L. Musacchio. 2002. Urbanization and warming of Phoenix (Arizona, USA): Impacts, feedbacks and mitigation. Urban Ecosystems 6:188-203.

Brady, N.C., and R.R. Weil. 2002. The Nature and Properties of Soils. Prentice Hall, Upper Saddle River, NJ.

Holman, J.P. 1986. Heat Transfer. McGraw-Hill Book Company, New York, NY.

Iles, J.K., and M.S. Dosmann. 1999. Effect of organic and mineral mulches on soil properties and growth of Fairview Flame ${ }^{\circledR}$ red maple trees. Journal of Arboriculture 25:163-167.

Kraus, H.T. 1998. Effects of mulch on soil moisture and growth of desert willow. HortTechnology 8:588-590.

Li, X.-Y. 2003. Gravel-sand mulch for soil and water conservation in the semiarid loess region of northwest China. CATENA 52:105-127.

Litzow, M., and H. Pellett. 1983. Influence of mulch materials on growth of green ash. Journal of Arboriculture 9:7-11.

Martin, C.A. 2001. Landscape water use in Phoenix, Arizona. Desert Plants 17:26-31.

Montague, T., and R. Kjelgren. 2004. Energy balance of six common landscape surfaces and the influence of surface properties on gas exchange of four containerized species. Scientia Horticulturae 100: 229-249.

Montague, T., R. Kjelgren, and L. Rupp. 1998. Surface energy balance affects gas exchange of three shrub species. Journal of Arboriculture 24:254-262.

- 2000. Surface energy balance affects gas exchange and growth of two irrigated landscape tree species in an arid climate. Journal of the American Society for Horticultural Science 125:299-309.

Montague, T., C. McKenney, M. Maurer, and B. Winn. 2007. Influence of irrigation volume and mulch on establishment of select shrub species. Arboriculture and Urban Forestry 33:202-209.

Pickering, J.S., A.D. Kendle, and P. Hadley. 1998. The suitability of composted green waste as an organic mulch: Effects on soil moisture retention and surface temperature. Acta Horticulturae 469:319-324.

Skroch, W.A., M.A. Powell, T.E. Bilderback, and P.H. Henry. 1992. Mulches: Durability, aesthetic value, weed control, and temperature. Journal of Environmental Horticulture 10:43-45.

Smith, A.M., and D.A. Rakow. 1992. Strategies for reducing water input in woody landscape plantings. Journal of Arboriculture 18:165-170.

U.S. Government. 2002. Healthy Forests Initiative. www.healthyforests.gov/initiative/index.html (accessed 5/21/07).

van Donk, S.J., and E.W. Tollner. 2001. Measuring and modeling heat transfer parameters in mulches. Acta Horticulturae 566:447-453.

van Wesemael, B., J. Poesen, C.S. Kosmas, N.G. Danaloatos, and J. Nachtergaele. 1996. Evaporation from cultivated soils containing rock fragments. Journal of Hydrology 182:65-82.

Chris A. Martin (corresponding author)

Arizona State University

Applied Biological Sciences

7001 East Williams Field Road

Building 130

Mesa, AZ 85212, U.S.

chris.martin@asu.edu

Catherine K. Singer

Arizona State University

Applied Biological Sciences

7001 East Williams Field Road

Building 130

Mesa, AZ 85212, U.S. 
Résumé. Les effets de trois paillis utilisés en paysagement - résidus compostés de pin ponderosa, résidus non compostés d'élagage et résidus de pierre de granit - ont été comparés durant deux ans (2004 et 2005) en regard de leur capacité à modifier les microclimats au niveau de l'air et du sol des aménagements à Phoenix en Arizona. Les paillis n'ont eu aucune influence sur les flux nets de radiation à $1 \mathrm{~m}$ au-dessus du sol durant la période des heures du jour. Cependant, durant la période nocturne, les radiations à longue longueur d'onde étaient généralement plus faibles avec les deux paillis organiques comparativement au paillis minéral ou au sol sans paillis. Les températures à la surface des deux paillis organiques étaient plus élevées durant le jour et plus faibles durant la nuit comparativement au paillis minéral ou au sol sans paillis. Le transfert de chaleur par conduction avec les paillis organiques étaient généralement plus faibles qu'avec le paillis minéral. Les températures du sol à 5 et $30 \mathrm{~cm}$ de profondeur étaient plus faibles avec les paillis organiques qu'avec le paillis minéral ou le sol sans paillis. Le sol recouvert de paillis organique perdait moins d'eau par évaporation que le sol sans paillis. Sous des conditions désertiques, les paillis organiques étaient plus efficaces pour diminuer le gain en chaleur et la perte en eau du sol que le paillis minéral, et ce en raison de la résistance accrue au transfert de chaleur et à l'évaporation.

Zusammenfassung. In Phoenix, Arizona wurden die Wirkungen von drei Mulchen: 1) kompostierter Kiefernmulch, 2) unkompostiertes Schreddergut und 3) gesiebter Granit über einen Zeitraum von zwei Jahren (2004-05) auf ihre Fähigkeit zur Verbesserung der Luft- und Boden-Mikroklimata untersucht. Die Mulche hatten tagsüber keinen Einfluss auf die Netto-Strahlung in ca. $1 \mathrm{~m}$ über dem Boden. Dennoch, die nächtliche Langwellen-Strahlungswerte waren über den beiden or- ganischen Mulchen allgemein niedriger als über dem Granit oder ungemulchten Boden. Die Temperaturen auf der Oberfläche der zwei organischen Mulche waren tagsüber höher und nachts niedriger als bei dem Granit oder ungemulchten Boden. Die Hitzeleitung durch die organischen Mulche war allgemein niedriger als durch den Granit. Die Bodentemperaturen bei 5 und $30 \mathrm{~cm}$ Tiefe waren unter der zwei organischen Mulchen niedriger als unter dem Granit oder ungemulchten Boden. Boden mit organischer Abdeckung evaporierte weniger als unbedeckter Boden. Unter Wüstenbedingungen waren die beiden organischen Mulche wegen ihres stärkeren Widerstands gegen Hitze und Evaporation effektiver bei dem Temperaturausgleich und dem Wasserverlust als der Granit.

Resumen. Los efectos de tres mulches: 1) composta de residuos de pino ponderosa, 2) desechos no composteados de árboles, y 3) granito, fueron comparados en dos años (2004-5) para conocer su habilidad de modificar los microclimas en aire y suelo en Phoenix, Arizona. Los mulches no influyeron en los flujos de radiación neta, $1 \mathrm{~m}$ arriba del piso durante las horas diurnas. Sin embargo, las radiaciones de onda larga nocturnas fueron generalmente más bajas en los dos mulches orgánicos comparados con el mulch de granito o el suelo sin mulch. La transferencia de calor a través de los mulches orgánicos fue generalmente mas baja que en el granito. Las temperaturas del suelo a profundidades de 5 y $30 \mathrm{~cm}$ fueron mas bajas debajo de los dos mulches orgánicos que bajo el granito o el suelo desnudo. El suelo cubierto con mulch orgánico evaporó menos agua que el suelo sin mulch. Bajo condiciones desérticas los dos mulches orgánicos fueron más efectivos en moderación de calor y pérdida de agua del suelo que el mulch de granito, debido a una resistencia a la transferencia de calor y evaporación. 